
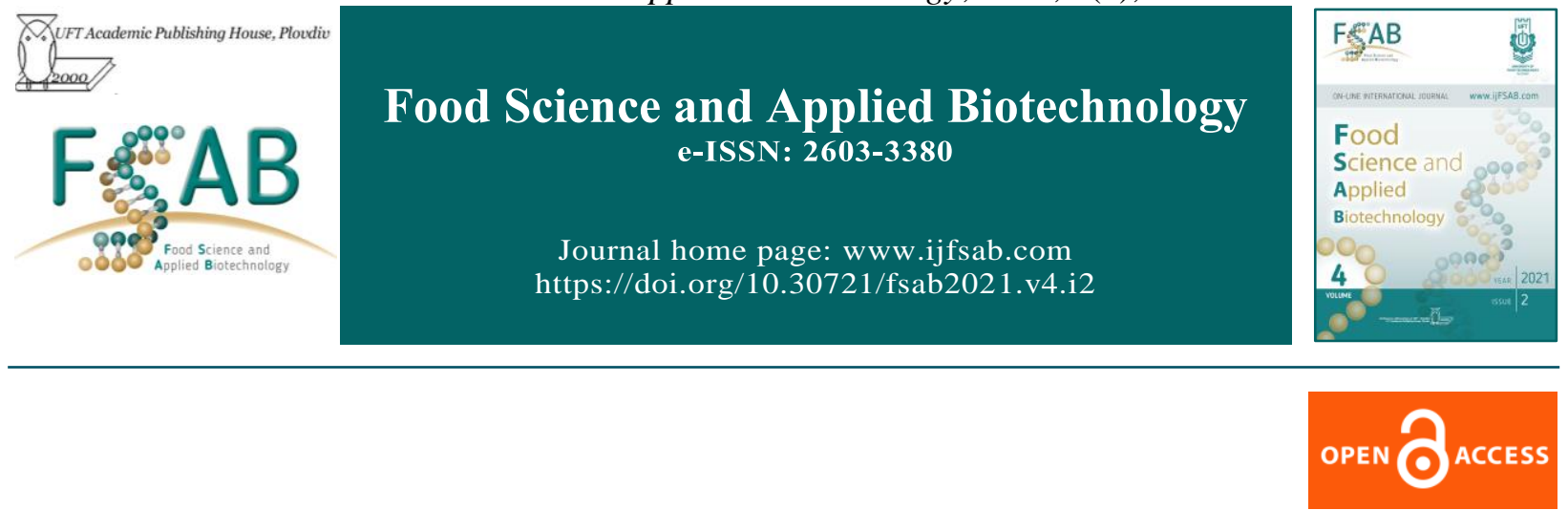

Research Article

\title{
Evaluation of sugar and free amino acid during fermentation of ogi from maize, acha and sorghum
}

Adekunbi Adetola Malomo ${ }^{1 \unrhd}$, Babatunde Olawoye ${ }^{2}$, Abiola Folakemi Olaniran ${ }^{3}$, Omowumi Ibipeju Olaniyi ${ }^{1}$, Adedoyin Adedayo ${ }^{1}$, Hezekiah Adekanmi Adeniran ${ }^{1}$, Sumbo Henrietta Abiose ${ }^{1}$

${ }^{1}$ Department of Food Science and Technology Obafemi Awolowo University, Ile - Ife, Nigeria.

${ }^{2}$ Department of Food Science, Technical University, Nigeria

${ }^{3}$ Department of Food Science, Landmark University, Omu-Aran, Nigeria.

\begin{abstract}
This research investigated effect of fermentation time and cereal type on the total reducing sugar (TRS), total sugar (TSS), and total free amino acid (TFA) during the production of ogi. The result showed that TFA generally increased with increase in fermentation time $(7.916-17.596 \mathrm{mg} / \mathrm{g})$. Maize, acha and sorghum ogi had the lowest total reducing sugar (TRS) at $0 \mathrm{~h}(16.927 \mathrm{glucose} \mathrm{mg} / \mathrm{g}), 12 \mathrm{~h}(16.655$ glucose $\mathrm{mg} / \mathrm{g})$ and $48 \mathrm{~h}(18.212$ glucose $\mathrm{mg} / \mathrm{g})$ respectively and TSS was lowest in acha ogi from $12 \mathrm{~h}$ to $48 \mathrm{~h}$ (33.191 - 34.370 glucose mg/g). Principal component analysis and Agglomerative hierarchical clustering were used to evaluate the variability in sugar and amino acid contents and ranked the contributions of the variables. The factors were divided into four principal components with cumulative variance contribution rate of $87.47 \%$. The result showed that $a c h a$ and sorghum ogi had lower sugar content than maize ogi during fermentation. This research suggested that maize, acha and sorghum can be used in the production of cereal based ogi for weaning food at $48 \mathrm{~h}$ due to high free amino acid content, and also advanced the use of acha in production of $o g i$ for diabetic patients due to its low total sugar content.
\end{abstract}

Keywords: Acha, ogi, sugar, amino acid, sorghum, maize

Abbreviations: A - acha; $\mathrm{M}$ - maize; $\mathrm{S}$ - sorghum.

${ }^{\square}$ Corresponding author: Dr. Adekunbi Malomo, Department of Food Science and Technology, Faculty of Technology, Obafemi Awolowo University, Ile - Ife, Nigeria, +2348068160388; E-mail: adepojuadekunbi@gmail.com

Article history:

Received 18 December 2020

Reviewed 18 February 2021

Accepted 24 March 2021

Available on-line 01 April 2021

https://doi.org/10.30721/fsab2021.v4.i2.136 (C) 2021 The Authors. UFT Academic publishing house, Plovdiv 


\section{Introduction}

$O g i$ is a fermented cereal gruel or porridge made from maize (Zea mays) or corn; sorghum (Sorghum vulgare) or millet (Pennisetum typhoideum). The choice of grain depends on preference and ethnicity of the producer (Ohenhen and Ikennebomeh 2007). Ogi, usually called pap, akamu and koko by the people of West Africa can be processed into a slurry paste by heating in boiling water under constant stirring (Adeshokan et al. 2010). It is produced by steeping cereal in water for $72 \mathrm{~h}$ at ambient temperature and wet milling (Ohenhen and Ikennebomeh 2007). Fermentation and fermentation period after wet milling depend on individual preference. $O g i$ slurry usually has a smooth texture, a sour flavour resembling that of yoghurt and a characteristic aroma that differentiates it from starch and flour (Omemu 2011).

Acha (Digitaria exilis) also known as Fonio, Findi, Funde, Pom, and Kabug is a highly nutritious cereal crop of West African origin belonging to the family Graminaea (Oyetayo and Agbaje 2012; Malomo et al. 2018) is a lesser-known cereal rich in vitamins, minerals, fiber, carbohydrate, protein, amino acids. It is important because it is high in methionine and cysteine lacking in wheat, rice, maize and other cereal crops and also have low glycemic index which could be an advantage in type II diabetic condition (Alegbejo et al. 2011; Ukeyima 2019).

Fermentation of cereals has been reported to increase acidity, total free amino acids and their derivatives by proteolysis and/or by metabolic synthesis. This process reduces the $\mathrm{pH}$ thereby inhibiting pathogenic organisms (Kohajdová and Karovičová 2007; Malomo et al. 2018) and also improves the rheological properties, acidification, taste and flavour of fermented foods (Malomo et al. 2019). Starch digestibility also increases during fermentation and this could be due to enzymatic properties of fermenting microflora that brings about the breakdown of starch into simple sugar (Mugula et al, 2003; Malomo et al, 2019). The microorganisms involved in fermentation of food increases palatability and improve the quality of food by increasing the availability of proteins and vitamins (Ogodo et al, 2019). Many researchers have worked on ogi (Omemu et al, 2011; Olaniran et al, 2019) but there is dearth of information on effect of fermentation on sugars and free amino acid. Fermentation may have direct effect on the taste, sugars, total free amino acid and other properties of ogi. Ogi intended for weaning food should be high in free amino acid and those intended for diabetic patient supposed to have lower sugar content. Therefore, this present study was carried out to determine the effect fermentation time and different cereal "maize (Zea mays), acha (Digitaria exilis) and sorghum (Sorghum bicolor)" on the total sugar, total reducing sugar and total free amino acid of ogi.

\section{Materials and Methods}

Procurement of materials. Quality protein maize (ART/98/SW06/OB/W) was obtained from the Institute of Agricultural Research and Training (I.A.R.T.), Ibadan, Nigeria. Sorghum (red variety) was purchased from a local market in Ile-Ife, Osun State, Nigeria. Acha grain was obtained from a local market in Zaria, Nigeria and the identity were ascertained at the herbarium of the Department of Botany, Obafemi Awolowo University, Ile-Ife, Nigeria. Chemicals used for analysis were obtained from Sigma-Aldrich and were of analytical grade.

Production of ogi. The cereals (maize, acha and sorghum) were sorted, weighed and steeped separately for $72 \mathrm{~h}$. The grains were drained and wet-milled into slurry using an attrition mill. The ogi $(100 \mathrm{ml})$ obtained was dispensed into sterile plastics and fermented for $48 \mathrm{~h}$ (Olaniran et al. 2019).

Extraction of sugar from $O g i$ samples. $O g i$ samples from maize, acha and sorghum were picked at six-hour interval for extraction. The samples were dried in Gallenkamp oven at $45^{\circ} \mathrm{C}$ for $10 \mathrm{~h}$, ground in a blender (USHA MG $2053 \mathrm{~N}$, India) and sieved using $50 \mu \mathrm{m}$. Ogi sample (5 g) was weighed and thoroughly mixed in a conical flask containing 50 $\mathrm{ml}$ of $80 \%$ ethanol $\mathrm{v} / \mathrm{v}$ and $10 \mathrm{ml}$ of petroleum ether was added. The ethanol-petroleum ether suspension was stirred at room temperature for $30 \mathrm{~min}$ in magnetic stirrer (Lab-line, Model No 1580-1, U.S.A.) and mixture was transferred into centrifuge tubes and centrifuged (Bosch Model No TDL-5, Germany) at $5000 \mathrm{rpm}$ for $30 \mathrm{~min}$. The petroleum ether phase was discarded and the clear ethanol phase was kept in the refrigerator for further analysis (Malomo et al. 2019). 
Determination of total reducing sugar. Ethanolic extract $(1 \mathrm{ml})$ was measured into each test tube; 2 $\mathrm{ml}$ of Dinitrosalicyclic acid reagent was added and boiled for $5 \mathrm{~min}$ at $100^{\circ} \mathrm{C}$ in Gallenkamp water bath (Gallenkomp, HH-S6, England) and cooled thoroughly under running water. Distilled water (7 ml) was added and the absorbance was read against reagent blank at $540 \mathrm{~nm}$ in a UV Spectrophotometer (Spectrumlab 752S, YM1206PHB2, China). The amount of reducing sugar in the samples was extrapolated from a standard curve of known concentrations of glucose $(0-1000 \mu \mathrm{g} / \mathrm{ml})$ (Adepoju et al. 2016).

Determination of total sugar. Total sugar was determined using the anthrone reagent method of Morris (1948) described by Malomo et al. (2019). Ethanolic extract $(1 \mathrm{ml})$ was added to $4 \mathrm{ml}$ of anthrone reagent, heated in boiling water bath (Gallenkomp, HH-S6, England) for $10 \mathrm{~min}$ and rapidly cooled. Absorbance was read at $620 \mathrm{~nm}$ against a reference blank in spectrophotometer (Spectrumlab 752S, YM1206PHB2, China) and the amount of sugar liberated was obtained from the standard curve based on known concentrations of glucose (10-100mg/l)

Determination of total free amino acid. $O g i$ samples $(5 \mathrm{~g})$ were weighed into $250 \mathrm{ml}$ conical flask and $50 \mathrm{ml}$ of $80 \%$ ethanol v/v was added. The suspension was mixed properly and $10 \mathrm{ml}$ of petroleum ether was added. The ethanol-petroleum ether suspension was stirred at room temperature for 30 min using a magnetic stirrer (Lab-line, Model No 1580-1, U.S.A) and centrifuged at $5000 \mathrm{rpm}$ for 30 min. The petroleum ether phase was discarded and the clear ethanol phase was used as the sample extract (Malomo et al. 2019). The ninhydrin method described by Rosen (1957) was used for determination of free amino acid. Cyanide acetate buffer $(0.5 \mathrm{ml}$ at $\mathrm{pH} 5.4)$ and $0.5 \mathrm{ml}$ of $3.0 \%$ ninhydrin solution ( $3 \mathrm{~g}$ of ninhydrin in $100 \mathrm{ml}$ of 2methyl ethanol) was added to the extract $(1.0 \mathrm{ml})$ in test tube and heated in boiling water bath (Gallenkomp, HH-S6, England) for $15 \mathrm{~min}$. Isopropyl-alcohol water mixture $(10 \mathrm{ml})$ at ratio 1:1 was added rapidly and the solution was allowed to cool to room temperature $\left(27 \pm 2^{\circ} \mathrm{C}\right)$. The absorbance was read at $570 \mathrm{~nm}$ using spectrophotometer (Spectrumlab 752S, YM1206PHB2, China). Total free amino acid in the samples was obtained from a standard curve of known concentrations of glycine $(10-100 \mu \mathrm{m} / \mathrm{ml})$ (concentrations of glucose (10$100 \mathrm{mg} / \mathrm{l})($ Omafuvbe 2000).

Statistical analysis. Data obtained were subjected to descriptive and inferential statistics using SPSS (version, SPSS, Inc., USA). Means of samples were separated using Duncan Multiple range Test (SAS Institute 1985). Principal component and clustered analysis were carried out on the data obtained using XLSTAT 2016 (Addinsoft Inc. USA).

\section{Results and Discussion}

Total free amino acid of $o g i$ powder at different stages of fermentation. The total free amino acid (Table 1) generally increased from the beginning of fermentation to $36 \mathrm{~h}$ and slightly decreased from 36 $\mathrm{h}$ to $48 \mathrm{~h}$ in maize and sorghum ogi. It was significantly higher $(\mathrm{p}<0.05)$ in ogi produced from maize $(9.788-17.600 \mathrm{mg} / \mathrm{g})$ than sorghum $(8.474$ $16.610 \mathrm{mg} / \mathrm{g})$ and $a c h a(7.916-16.607 \mathrm{mg} / \mathrm{g})$ from 0 $\mathrm{h}$ to $24 \mathrm{~h}$ but there was no significant difference ( $\mathrm{p}$ $>0.05$ ) from $36 \mathrm{~h}$ to $48 \mathrm{~h}$. There was no significant difference $(p>0.05)$ between ogi produced from sorghum and acha from $12 \mathrm{~h}$ to $48 \mathrm{~h}$ of fermentation. The total free amino acid of $o g i$ produced from sorghum and acha had similar total free amino acid content throughout the period of fermentation. Malomo et al. (2019) also reported increase in total free amino acid during fermentation of $a c h a$ and maize and attributed it to the proteolytic activities of fermenting organisms.

Total reducing sugar ogi at different stages of fermentation. The total reducing sugar was highest in maize ogi from $12 \mathrm{~h}$ to $36 \mathrm{~h}$ (20.544 - 23.591 glucose $\mathrm{mg} / \mathrm{g}$ ) and was not significantly ( $\mathrm{p}>0.05$ ) different from acha ogi at $48 \mathrm{~h}$. It was higher in sorghum ogi than acha ogi from $0 \mathrm{~h}$ to $12 \mathrm{~h}$ while acha had significantly higher $(\mathrm{p}<0.05)$ than sorghum ogi from $36 \mathrm{~h}$ to $48 \mathrm{~h}$ of fermentation. Malomo et al. (2019) also reported that the total reducing sugar of fermenting maize was higher than that of acha during fermentation. The range of result of this work is in agreement with the report of Olaniran et al. (2019). 
Table 1. Total free amino acid of ogi powder at different stages of fermentation, $\mathrm{mg} / \mathrm{g}$

\begin{tabular}{cccccc}
\hline Samples & $\mathbf{5}$ & $\mathbf{1 2}$ & $\mathbf{2 4}$ & $\mathbf{3 6}$ & $\mathbf{4 8}$ \\
\hline $\mathrm{A}$ & $7.916^{\mathrm{b}} \pm 0.114$ & $13.607^{\mathrm{b}} \pm 0.211$ & $16.607^{\mathrm{b}} \pm 0.284$ & $17.344^{\mathrm{a}} \pm 0.890$ & $17.560^{\mathrm{a}} \pm 0.060$ \\
$\mathrm{M}$ & $9.788^{\mathrm{a}} \pm 0.414$ & $14.609^{\mathrm{a}} \pm 0.200$ & $17.600^{\mathrm{a}} \pm 0.092$ & $17.632^{\mathrm{a}} \pm 0.100$ & $17.596^{\mathrm{a}}{ }^{ \pm} 0.100$ \\
$\mathrm{~S}$ & $8.474^{\mathrm{a}} \pm 0.150$ & $13.607^{\mathrm{b}} \pm 0.241$ & $16.610^{\mathrm{b}} \pm 0.217$ & $17.686^{\mathrm{a}} \pm 0.200$ & $17.524^{\mathrm{a}} \pm 0.040$ \\
\hline
\end{tabular}

Values are means of three replicates \pm standard error.

Means followed by different superscript in the same column are significantly different at $\mathrm{p}<0.05$.

Total reducing sugar ogi at different stages of fermentation. The total reducing sugar was highest in maize ogi from $12 \mathrm{~h}$ to $36 \mathrm{~h}(20.544-23.591$ glucose $\mathrm{mg} / \mathrm{g}$ ) and was not significantly $(\mathrm{p}>0.05)$ different from acha ogi at $48 \mathrm{~h}$. It was higher in sorghum ogi than acha ogi from $0 \mathrm{~h}$ to $12 \mathrm{~h}$ while acha had significantly higher $(\mathrm{p}<0.05)$ than sorghum $o g i$ from $36 \mathrm{~h}$ to $48 \mathrm{~h}$ of fermentation. Malomo et al. (2019) also reported that the total reducing sugar of fermenting maize was higher than that of acha during fermentation. The range of result of this work is in agreement with the report of Olaniran et al. (2019).

Table 2. Total reducing sugar ogi at different stages of fermentation, glucose $\mathrm{mg} / \mathrm{g}$

\begin{tabular}{cccccc}
\hline Samples & $\mathbf{5}$ & $\mathbf{1 2}$ & $\mathbf{2 4}$ & $\mathbf{3 6}$ & $\mathbf{4 8}$ \\
\hline $\mathrm{A}$ & $17.689^{\mathrm{b}} \pm 0.200$ & $16.655^{\mathrm{c}} \pm 0.304$ & $20.540^{\mathrm{a}} \pm 0.210$ & $20.925^{\mathrm{b}} \pm 0.445$ & $19.164^{\mathrm{a}} \pm 0.164$ \\
$\mathrm{M}$ & $16.927^{\mathrm{c}} \pm 0.100$ & $20.544^{\mathrm{a}} \pm 0.100$ & $23.448^{\mathrm{a}}{ }^{\mathrm{b}} \pm 0.200$ & $23.591^{\mathrm{a}} \pm 0.009$ & $19.069^{\mathrm{a}} \pm 0.069$ \\
$\mathrm{~S}$ & $18.355^{\mathrm{b}} \pm 0.945$ & $19.162^{\mathrm{b}} \pm 0.520$ & $20.449^{\mathrm{a}} \pm 0.002$ & $19.164^{\mathrm{c}} \pm 0.091$ & $18.212^{\mathrm{b}} \pm 0.244$ \\
\hline
\end{tabular}

Values are means of three replicates \pm standard error.

Means followed by different superscript in the same column are significantly different at $\mathrm{p}<0.05$.

Table 3. Total sugar in $o g i$ at different stages of fermentation, glucose $\mathrm{mg} / \mathrm{g}$

\begin{tabular}{cccccc}
\hline Samples & $\mathbf{5}$ & $\mathbf{1 2}$ & $\mathbf{2 4}$ & $\mathbf{3 6}$ & $\mathbf{4 8}$ \\
\hline $\mathrm{A}$ & $39.335^{\mathrm{a}} \pm 0.300$ & $36.767^{\mathrm{b}} \pm 0.112$ & $33.191^{\mathrm{b}} \pm 0.297$ & $32.191^{\mathrm{c}} \pm 0.410$ & $34.370^{\mathrm{c}} \pm 0.112$ \\
$\mathrm{M}$ & $39.049^{\mathrm{a}} \pm 0.490$ & $40.018^{\mathrm{a}} \pm 0.231$ & $39.085^{\mathrm{a}} \pm 0.2130$ & $40.086^{\mathrm{b}} \pm 0.311$ & $37.156^{\mathrm{b}} \pm 0.128$ \\
$\mathrm{~S}$ & $30.333^{\mathrm{b}} \pm 0.210$ & $32.543^{\mathrm{c}} \pm 0.102$ & $33.262^{\mathrm{c}} \pm 0.381$ & $37.159^{\mathrm{a}} \pm 0.094$ & $38.764^{\mathrm{a}} \pm 0.086$ \\
\hline
\end{tabular}

Values are means of three replicates \pm standard error.

Means followed by different superscript in the same column are significantly different at $\mathrm{p}<0.05$.

Total sugar in ogi at different stages of fermentation. The total sugar content of ogi was highest in ogi produced from acha $(39.335$ glucose $\mathrm{mg} / \mathrm{g}$ ) and lowest in ogi produced from sorghum (30.333 glucose $\mathrm{mg} / \mathrm{g}$ ) at the beginning of fermentation. It was lowest in achaogi between 24

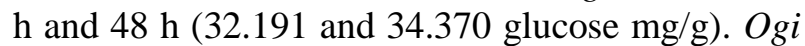
produced from maize had the highest total sugar content from the beginning of fermentation to the 36 h (37.156 - 40.086 glucose mg/g). The breaking down of complex carbohydrate into simple sugar by fermenting microorganism and utilization of these sugars as carbon source could be responsible for fluctuation in total sugar (Oyarekua and Adeyeye 2009; Adepoju et al. 2016). The highest total sugar content in maize ogi could be due to high amount of digestible starch. Jideani and Podgorski (2009) and Jideani and Jideani (2011) reported the digestible 
starches (DS) of maize and acha to be 43.7 and 41.4 respectively. This suggest that acha could be consumed as food with low glycemic index.

PCA was applied to pooled measurements in order to describe the group of physical data, to establish the relationships between the different physical variables, and to detect the most important factors of variability.

Table 4. Eigenvalues of $o g i$ samples

\begin{tabular}{lccc}
\hline & PC1 & PC2 & PC3 \\
\hline Eigenvalue & 1.623 & 1.002 & 0.376 \\
Variability, \% & 54.086 & 33.384 & 12.530 \\
Cumulative, \% & 54.086 & 87.470 & 100.000 \\
\hline
\end{tabular}

The PCA with Eigenvalue more than 1 were selected. Table 4 showed that component PC1 and PC2 best represent the samples with Eigenvalues of 1.623 and 1.002 respectively. These components account for $87.470 \%$ of the total variance with PC1 having $54.086 \%$ and PC2 with $33.384 \%$ (Table 4). Total reducing sugar $(0.901)$ and Total free amino acid (0.889) were best represented in component 1 while the total sugar (0.987) was represented on component 2. Total reducing sugar (TRS) and total free amino acid have strong positive correlation as shown in Figure 1.

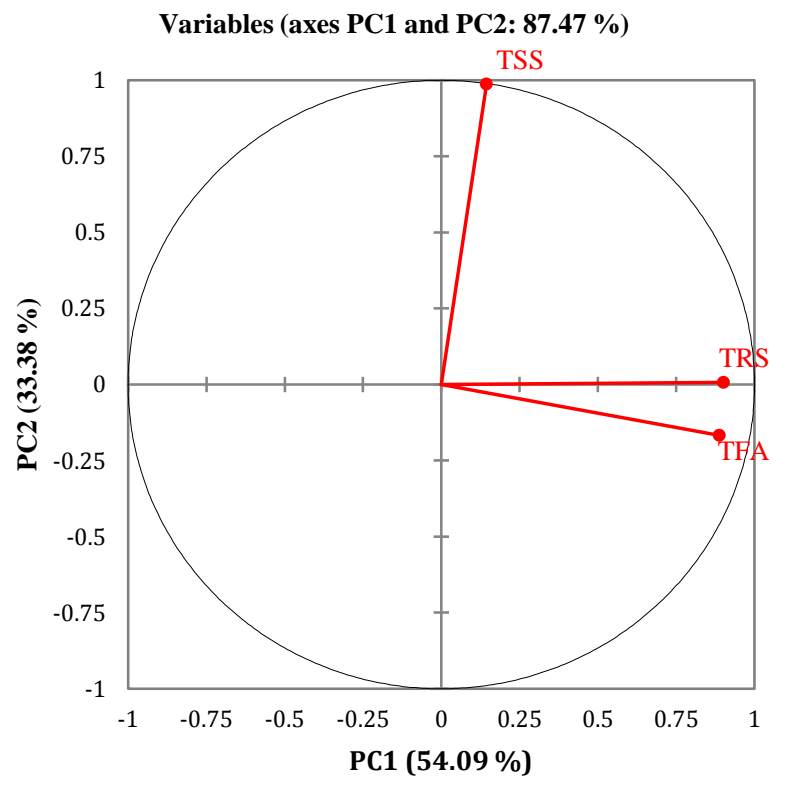

Figure. 1. The plot showing relationship between variables
Total sugar has weak positive correlation with Total reducing sugar and negative correlation with free amino acid. This was an indication that the decrease in the total sugar led to increase in total free amino acid.

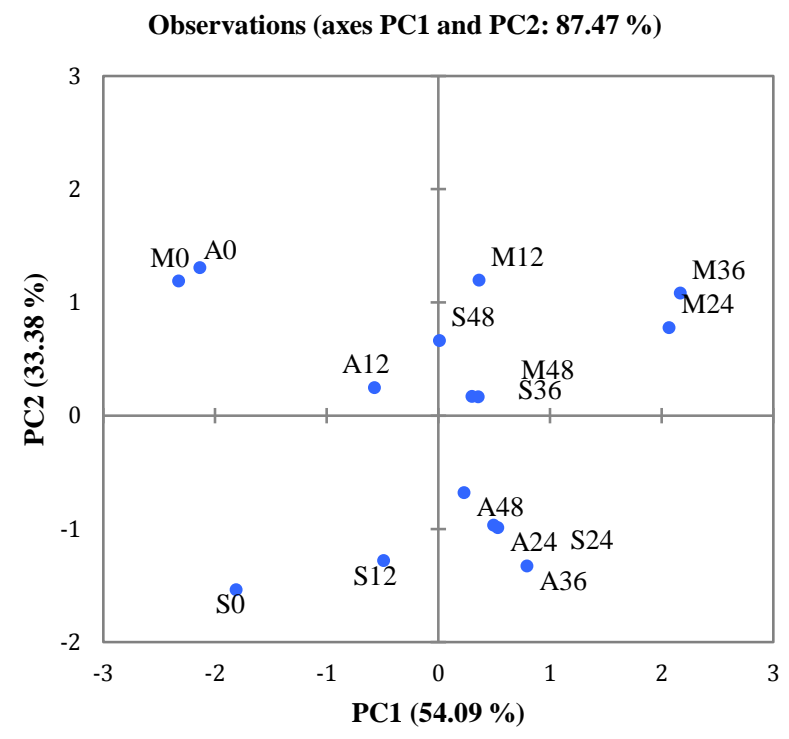

Figure 2. The plot showing relationship between observations

Samples were grouped according to the hour of fermentation (Fig. 2). Ogi produced from maize (M0), acha (A0), sorghum (S0) are represented at the negative side of $\mathrm{PC} 1$ at the beginning of fermentation. Ogi produced from acha (A12) at 12 $\mathrm{h}$, was also represented on the negative axis of PC2. Ogi produced from maize at $24 \mathrm{~h}$ (M24), $36 \mathrm{~h}$ (M36), $48 \mathrm{~h}$ (M48) and sorghum at $36 \mathrm{~h}$ (S36), are grouped together on the positive axis of component 1. Acha fermented for $24 \mathrm{~h}$ (A24) and $36 \mathrm{~h}$ (A36), and (A48) are grouped together at the negative axis of component 2 likewise $O g i$ produced from sorghum at $12 \mathrm{~h}(\mathrm{~S} 12)$ and $24 \mathrm{~h}(\mathrm{~S} 24)$ while $o g i$ maize fermented for $12 \mathrm{~h}$ (M12) and sorghum for 48 $\mathrm{h}$ (S48) were grouped on the positive axis of component 2.

Figure. 3 showed that maize $o g i$ had the highest total sugar and starch but were both higher in samples fermented at 12 and $48 \mathrm{~h}$ than at 0,24 and $36 \mathrm{~h}$. The Biplot (Fig. 3.) showed that total sugar (TSS) was high in maize ogi at $12 \mathrm{~h}, 24,36$ and $48 \mathrm{~h}$ and in sorghum at 36 and $48 \mathrm{~h}$. 


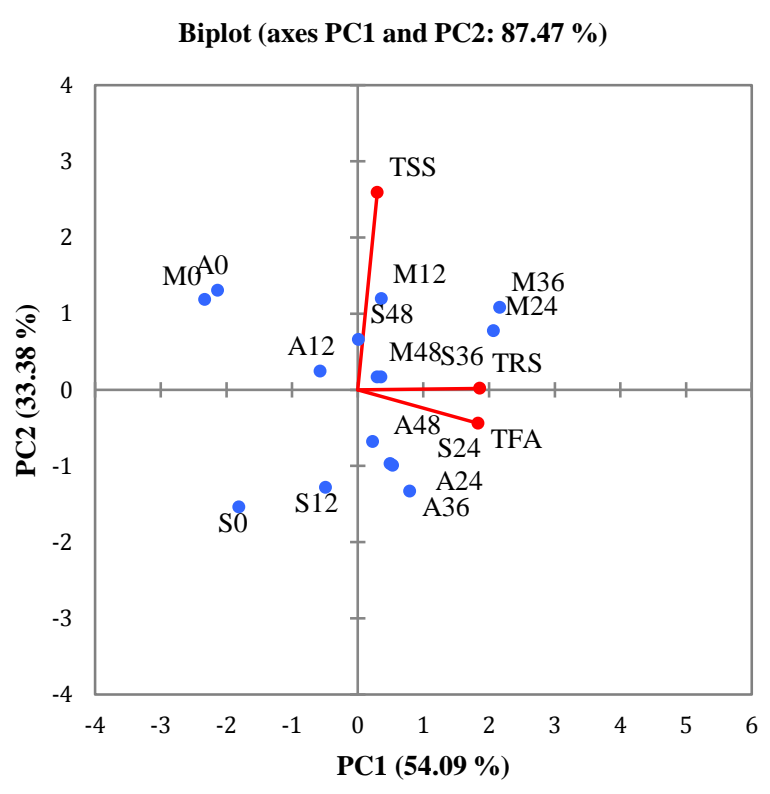

Figure 3. The Biplot showing relationship between variables and observations

Ogi produced from acha had negative correlation with total sugar from 0 hour to $12 \mathrm{~h}$ of fermentation. This showed the longer the fermentation time, the lower the total sugar in acha. It also has negative correlation with sorghum at the beginning of fermentation and at $12 \mathrm{~h}$ indicating that TSS increased in sorghum with increase in time of fermentation. Total free amino was low in all ogi powder samples at $0 \mathrm{~h}$ (A0, M0 and S0) and only had weak positive correlation at $12 \mathrm{~h}$ in maize ogi (M12). It was highest in sorghum at $36 \mathrm{~h}$, followed by maize $o g i$ at $48 \mathrm{~h}$. It also had strong correlation with achaogi fermented between 24 and $48 \mathrm{~h}$ and maize ogi fermented for 24 and $36 \mathrm{~h}$. Increase in fermentation time led to increase in total free amino acid (TFA) in all ogi samples produced. Total reducing sugar also increased with increase in fermentation time and was highest in ogi produced from maize.

Agglomerative hierarchical clustering showed that acha ogi (A0) and maize $O g i(\mathrm{M} 0)$ are related at the beginning of fermentation and are grouped in class one (Figure. 4). Ogi maize fermented between 12 and $48 \mathrm{~h}$ was related to acha ogi at $12 \mathrm{~h}$ in class two. Acha ogi fermented between 24 to 48 hours is related with sorghum ogi at $24 \mathrm{~h}$ in class 3 . Sorghum ogi fermented for $0 \mathrm{~h}$ and $12 \mathrm{~h}$ was grouped separately in class 4 . This shows that ogi from acha is more related to maize ogi than sorghum ogi in terms of total reducing sugar, total sugars and total free amino acid during fermentation of the slurry from these three cereals.

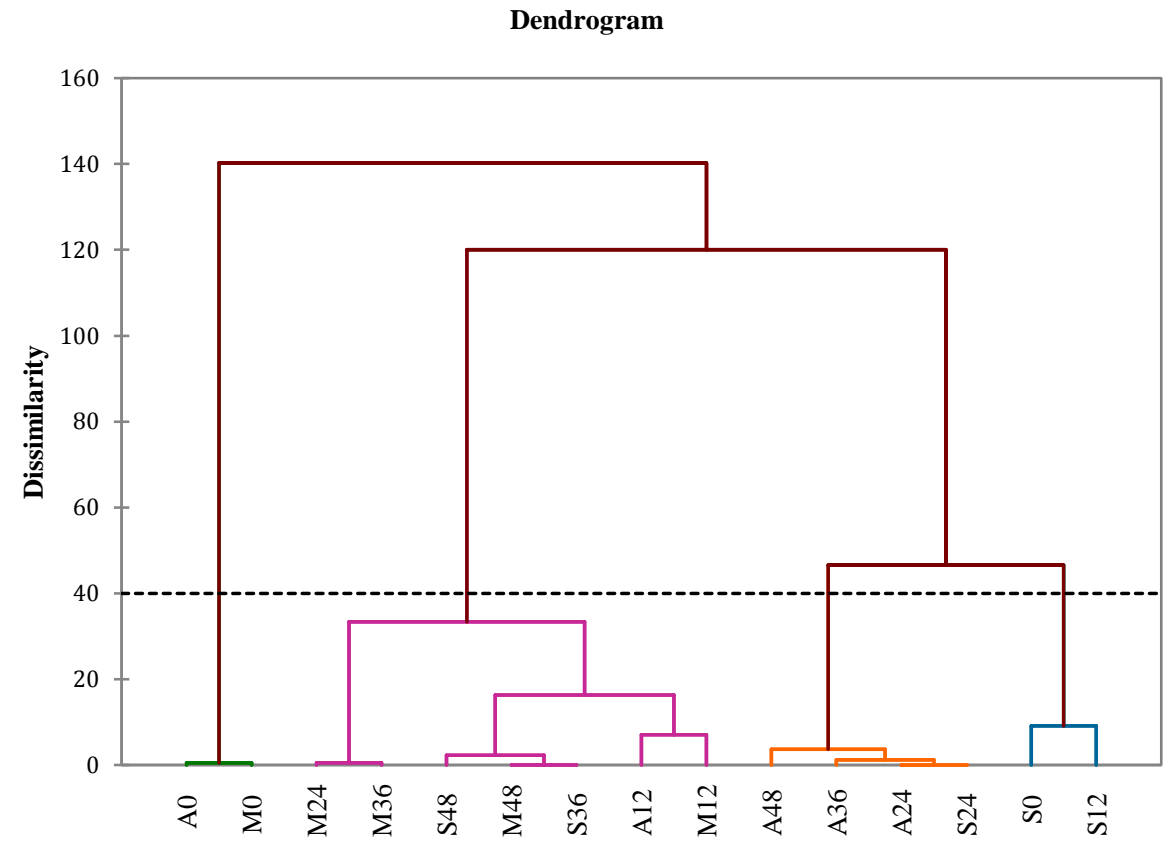

Figure 4. Agglomerative hierarchical clustering of ogi from maize, sorghum and acha 


\section{Conclusions}

The study showed that fermentation time and type of cereal affected the quantity of total sugar, total reducing sugar and total free amino acid available in ogi. Maize had the highest total sugar, total free amino acid and total reducing sugar. Though the initial total sugar of sorghum sample was low, it increased towards the end of fermentation. The choice of sorghum or acha for ogi with low glycemic index depends on the time of fermentation. It is suggested that the cereals meant for weaning should be fermented for $48 \mathrm{~h}$ because total free amino acid was highest at that point. $O g i$ produced from acha at $48 \mathrm{~h}$ is recommended for people living with Type II diabetes because it had the lowest sugar content and high total free amino acid which was not significantly different from maize and sorghum ogi.

\section{References}

Adesokan A., Abiola O.P., Ogundiya M.O. Influence of ginger on sensory properties and shelf-life of $o g i$, a Nigerian traditional fermented food. African Journal of Biotechnology, 2010, 9(12): 1803-1808. http://doi.org/10.5897/AJB10.1147

Adepoju A.A., Abiose S.H., Adeniran H.A. Effect of pasteurization and selected chemical preservatives on Fura de nunu during storage. African Journal of Food Science and Technology, 2016, 7(8): 178 185. http://doi.org/10.14303/ajfst.2016.102

Alegbejo_J.O., Ameh D.A., Ogala W., Ibrahim S. Glycemic index and load of acha (fonio) in healthy and diabetic subjects. Journal of Pure and Applied Microbiology, 2011, 5(1): 117-122. Available at: https://www.microbiologyjournal.org/archive mg/ imabsread.php? snoid=285\&month $=$ \&year $=$

Jideani V.A., Podgorski S.C. In-vitro starch digestibility and glycemic property of acha (Digitariaexilis) porridge. Cereal Foods World Supplement, 2009, 54(2): A48-A56. Available at: https://www.cerealsgrains.org/meetings/Document s/2009Abstracts/p09ma80.htm

Jideani A., Jideani V.A. Developments on the cereal grains Digitaria exilis (acha) and Digitaria iburua (iburu). Journal of Food Science and Technology, 2011, 48(3): 251-259. https://doi.org/10.1007/s13197-010-0208-9

Kohajdová Z., Karovičová J. Fermentation of cereals for specific purpose. Journal of Food and Nutrition Research, 2007, 46(2): 51-57. Available at: https://vup.sk/index.php?mainID $=1 \&$ navID $=36 \& \mathrm{v}$ ersion $=2 \&$ volume $=46 \&$ article $=817$
Malomo A.A., Abiose S.H., Adeniran H.A. Microbiological changes during the production of maize-acha masa fortified with soybean. Annals. Food Science and Technology, 2018, 19(2): 349357. Available at: http://www.afst.valahia.ro/images/documente/2018 /issue2/III.4_Adetola.pdf

Malomo A.A., Abiose S.H., Adeniran H.A. Effects of substitution of acha and soybean on alpha amylase activity, sugars and total free amino acid during production of maize masa. Journal of Microbiology, Biotechnology and Food Science, 2019, 9(3): 534-538. http://doi.org/10.15414/jmbfs.2019/20.9.3.534$\underline{538}$

Morris D.L. Quantitative determination of carbohydrate with dreywoods anthrone reagent. Science, 1948, 107(3): 254-255. http://doi.org/10.1126/science.107.2775.254

Mugula J.K., Narvhus, J.A., Sorhaug N.T. Use of starter cultures of lactic acid bacteria and yeasts in the preparation of togwa, a Tanzanian fermented food. International Journal of Food Microbiology, 2003, 83(3): 307-318. http://doi.org/10.1016/S01681605(02)00386-0

Ogodo A.C., Ugbogu O.C., Onyeagba R.A., Okereke H.C. Microbiological quality, proximate composition and in vitro starch/protein digestibility of Sorghum bicolor flour fermented with lactic acid bacteria consortia. Chemical and Biological Technology and Agriculture, 2019, 6(7): 1-9. https://doi.org/10.1186/s40538-0190145-4

Ohenhen R.E., Ikenebomeh M.J. Shelf stability and enzyme activity studies of ogi: A corn meal fermented product. Journal of American Science, 2007, 3(1): 34-42. Available at: http://citeseerx.ist.psu.edu/viewdoc/download?doi $=10.1 .1 .1078 .5566 \&$ rep $=$ rep $1 \&$ type $=$ pdf

Olaniran A.F., Abiose S.H., Gbadamosi S.O. Nutritional quality and acceptability evaluation of ogi flour biofortified with garlic and ginger. Journal of Health Science, 2019, 7: 101-109. http://doi.org/10.17265/2328-7136/2019.02.005

Omafuvbe B.O., Shonuka O.O., Abiose S.H. Microbiological and biochemical changes in the traditional fermentation of soybean for soydaddawa - Nigerian food condiment. Food Microbiology, 2000, 17(2019): 469-474. http://doi.org/10.1006/fmic.1999.0332

Omemu A.M. Fermentation dynamics during production of $o g i$, a Nigerian fermented cereal porridge. Report and Opinion, 2011, 3(4): 8-17. Available at: http://www.sciencepub.net/report/report0304/02_5 339report0304_8_17.pdf 
Oyarekua M.A., Adeyeye E.I. Comparative evaluation of the nutritional quality functional properties and amino acid profile of co-fermented maize/cowpea and sorghum/cowpea ogi as infant complementary food. Asian Journal of Clinical Nutrition, 2009, 1(1): 31-39. http://doi.org/10.3923/ajen.2009.31.39

Oyetayo V.O., Agbaje R.B. Effect of different processing methods on the micronutrient and amino acid composition of Digitaria exilis (Kippist) stapf. Journal of Life Sciences, 2012, 6(2012): 365-369. http://doi.org/10.17265/1934$\underline{7391 / 2012.04 .002}$

Rosen, H. A modified ninhydrin colorimetric analysis for amino acids. Archives of Biochemistry and Biophysics, 1957, 67(1): 10-15. http://doi.org/10.1016/0003-9861(57)90241-2

SAS/STAT user's guide, v. 9.3. Cary, NC, USA, SAS Institute, Inc. 2011. Available at: https://support.sas.com/documentation/cdl/en/statu g/63962/PDF/default/statug.pdf

Ukeyima M.T., Acham I.O., Awojide C.T. Quality evaluation of ogi from acha (Digitaria exilis), soybean (Glycine max) and carrot (Daucus carota L.) composite flour. Asian Journal of Biotechnology and Bioresource Technology, 2019, 5(2): 1-11. http://doi.org/10.9734/ajb2t/2019/ v5i230054 